\title{
GEOCHEMISTRY OF CORE SAMPLES OF THE TIVA CANYON TUFF FROM DRILL HOLE UE-25 NRG\#3, YUCCA MOUNTAIN, NEVADA
}

\section{U.S. GEOLOGICAL SURVEY}

Open-File Report 95-325

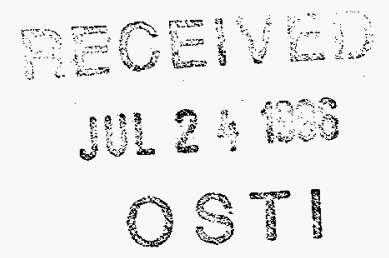

Prepared in cooperation with the NEVADA OPERATIONS OFFICE, U.S. DEPARTMENT OF ENERGY under Interagency Agreement DE-AI08-92NV10874

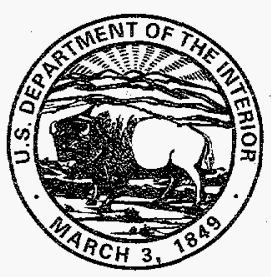



GEOCHEMISTRY OF CORE SAMPLES OF THE TIVA CANYON TUFF FROM DRILL HOLE UE-25 NRG\#3, YUCCA MOUNTAIN, NEVADA

by Zell E. Peterman and Kiyoto Futa

U.S. GEOLOGICAL SURVEY

Open-File Report 95 -325

Prepared in cooperation with the

NEVADA OPERATIONS OFFICE,

U.S. DEPARTMENT OF ENERGY under

Interagency Agreement DE-Al08-92NV10874

Denver, Colorado

1996 


\title{
U.S. DEPARTMENT OF THE INTERIOR BRUCE BABBITT, Secretary \\ U.S. GEOLOGICAL SURVEY \\ Gordon P. Eaton, Director
}

\section{DISCLAIMER}

\begin{abstract}
This report was prepared as an account of work sponsored by an agency of the United States Government. Neither the United States Government nor any agency thereof, nor any of their employees, makes any warranty, express or implied, or assumes any legal liability or responsibility for the accuracy, completeness, or usefulness of any information, apparatus, product, or process disclosed, or represents that its use would not infringe privately owned rights. Reference herein to any specific commercial product, process, or service by trade name, trademark, manufacturer, or otherwise does not necessarily constitute or imply its endorsement, recommendation, or favoring by the United States Government or any agency thereof. The views and opinions of authors expressed herein do not necessarily state or reflect those of the United States Government or any agency thereof.
\end{abstract}

The use of trade, product, industry, or firm names is for descriptive purposes only and does not imply endorsement by the U.S. Government.

For additional information write to:

Chief, Earth Science Investigations

Program

Yucca Mountain Project Branch

U.S. Geological Survey

Box 25046, MS 421

Denver Federal Center

Denver, CO 80225
Copies of this report can be purchased from:

U.S. Geological Survey

Earth Science Information Center

Open-File Reports Section

Box 25286, MS 517

Denver Federal Center

Denver, CO 80225 
DISCLAIMER

Portions of this document may be illegible in electronic image products. Images are produced from the best available original document. 



\section{CONTENTS}

Abstract

Introduction

Purpose and scope

Study methods

Lithostratigraphic and chemostratigraphic framework

Geochemistry of core samples from UE-25 NRG\#3

Summary

References cited

\section{FIGURES}

1. Map showing location of drill hole UE-25 NRG\#3 and selected geographic features

2-11. Graphs showing:

2. Composite geochemical profiles for samples from the Antler Ridge (circles), Whaleback Ridge (diamonds), and Solitario Canyon (squares) reference sections

3. Concentrations of $\mathrm{Ti}, \mathrm{Zr}$, and $\mathrm{Ba}$ in samples of the Tiva Canyon Tuff from drill hole UE-25 NRG\#3 ............. 9

4. Concentration of $\mathrm{Ca}$ in samples of the Tiva Canyon Tuff from drill hole UE-25 NRG\#3 .............................. 10

5. Concentration of $\mathrm{Sr}$ in samples of the Tiva Canyon Tuff from drill hole UE-25 NRG\#3 .............................. 11

6. Concentrations of $\mathrm{La}$ and $\mathrm{Ce}$ in samples of the Tiva Canyon Tuff from drill hole UE-25 NRG\#3 ................... 12

7. Concentrations of $\mathrm{Nb}$ and $\mathrm{Rb}$ in samples of the Tiva Canyon Tuff from drill hole UE-25 NRG\#3 .................. 13

8. Concentrations of $\mathrm{K}$ in samples of the Tiva Canyon Tuff from drill hole UE-25 NRG\#3 .............................. 14

9. Variations of $\mathrm{K} / \mathrm{Rb}$ ratio in samples of the Tiva Canyon Tuff from drill hole UE-25 NRG\#3 ....................... 15

10. Variations of present-day and initial Sr-isotope ratios in samples of the Tiva Canyon Tuff from drill hole UE-25 NRG\#3

11. Comparison of element concentrations in selected samples of quartz latite with the mean values for high-silica thyolite in UE-25 NRG\#3

\section{TABLES}

1. Lithostratigraphic zonation of the Tiva Canyon Tuff in drill hole UE-25 NRG\#3 at Yucca Mountain, Nevada

2. Geochemical and isotopic data for core samples from drill hole UE-25 NRG\#3, Yucca Mountain, Nevada ......... 7

3. Mean compositions of the high-silica rhyolite of the Tiva Canyon Tuff, Yucca Mountain, Nevada ..................... 8

CONVERSION FACTORS AND VERTICAL DATUM

\begin{tabular}{rll}
\hline Multiply & By & To obtain \\
\hline foot (ft) & & meter \\
gram (g) & 0.3048 & ounce \\
inch (in.) & 0.03527 & centimeter \\
\hline
\end{tabular}

The following term also is used in this report: parts per million (ppm)

Sea level: In this report "sea level" refers to the National Geodetic Vertical Datum of 1929 (NGVD of 1929)-a geodetic datum derived from a general adjustment of the first-order level nets of both the United States and Canada, formerly called Sea Level Datum of 1929. 



\title{
Geochemistry of Core Samples of the Tiva Canyon Tuff from Drill Hole UE-25 NRG\#3, Yucca Mountain, Nevada
}

\author{
ByZell E. Peterman and Kiyoto Futa
}

\begin{abstract}
The Tiva Canyon Tuff of Miocene age is composed of crystal-poor, high-silica rhyolite overlain by a crystal-rich zone that is gradational in composition from high-silica rhyolite to quartz latite. Each of these zones is divided into subzones that have distinctive physical, mineralogical, and geochemical features. Accurate identification of these subzones and their contacts is essential for detailed mapping and correlation both at the surface and in the subsurface in drill holes and in the exploratory studies facility (ESF). This report presents analyses of potassium $(\mathrm{K})$, calcium $(\mathrm{Ca})$, titanium (Ti), rubidium $(\mathrm{Rb})$, strontium $(\mathrm{Sr})$, yttrium $(\mathrm{Y})$, zirconium $(\mathrm{Zr})$, niobium $(\mathrm{Nb})$, barium (Ba), lanthanum (La), and cerium (Ce) in core samples of the Tiva Canyon Tuff from drill hole UE-25 NRG\#3. The concentrations of most of these elements are remarkably constant throughout the high-silica rhyolite, but at its upper contact with the crystal-rich zone, $\mathrm{Ti}, \mathrm{Zr}, \mathrm{Ba}, \mathrm{Ca}$, $\mathrm{Sr}, \mathrm{La}, \mathrm{Ce}$, and $\mathrm{K}$ begin to increase progressively through the crystal-rich zone. . In contrast, $\mathrm{Rb}$ and $\mathrm{Nb}$ decrease, and $\mathrm{Y}$ remains essentially constant. Initial ${ }^{87} \mathrm{Sr} /{ }^{86} \mathrm{Sr}$ ratios are relatively uniform in the high-silica rhyolite with a mean value of 0.7117 , whereas initial ${ }^{87} \mathrm{Sr} /{ }^{86} \mathrm{Sr}$ ratios decrease upward in the quartz latite to values as low as 0.7090 .
\end{abstract}

\section{INTRODUCTION}

Yucca Mountain (fig. 1) is being evaluated for its suitability as a site for a potential high-level nuclearwaste repository (U.S. Department of Energy, 1988). The U.S. Geological Survey (USGS) is conducting site characterization studies for the Department of Energy Yucca Mountain Site Characterization Project under Interagency Agreement No. DE-AI08-92NV10874. These studies include detailed petrographic, geochem- ical, and isotopic analyses of samples of the volcanic rock units collected from drill cores and from outcrops to aid in the identification and lateral correlation of zonal features. This report presents geochemical and isotopic data obtained on core samples of the Tiva Canyon Tuff from drill hole UE-25 NRG\#3 (hereafter referred to as NRG\#3). This drill hole is located west of Exile Hill (fig. 1) at an altitude of 3,823 ft at $36^{\circ} 51^{\prime} 18^{\prime \prime} \mathrm{N}$ and $116^{\circ} 25^{\prime} 59^{\prime \prime} \mathrm{W}$ (Nevada State coordinates $766,251 \mathrm{~N}$ and $568,316 \mathrm{E}$ ). The drill hole has a plunge of $56.5^{\circ}$ on an azimuth of $95.2^{\circ}$. The total length of the drill hole is $330 \mathrm{ft}$. Geslin and others (1995) described the lithology and zonal features of the core, and their zonal designations are used in this report (table 1).

\section{Purpose and Scope}

The purpose of this study is to document the geochemical variations in the Tiva Canyon Tuff using energy-dispersive $\mathrm{X}$-ray fluorescence analyses of selected elements (K, Ca, Ti, Rb, Sr, Y, Zr, Nb, Ba, La, and $\mathrm{Ce}$ ). Drill hole NRG\#3 was selected because it intercepted a relatively complete section of the crystalrich zone, which is difficult to obtain in outcrop in a single section. Forty-nine samples of core from drill hole NRG\#3 were obtained for analyses. Sample spacing was designed to be representative of the main lithologic zones of the moderately and densely welded portions of the unit and to closely delineate the contact between the high-silica rhyolite and the transitional quartz latite.

\section{Acknowledgments}

The authors gratefully acknowledge the careful reviews by Dr. Thomas C. Moyer and Ms. Frances Singer (SAIC, Science Applications International). Samples of core from drill hole NRG\#3 were carefully 

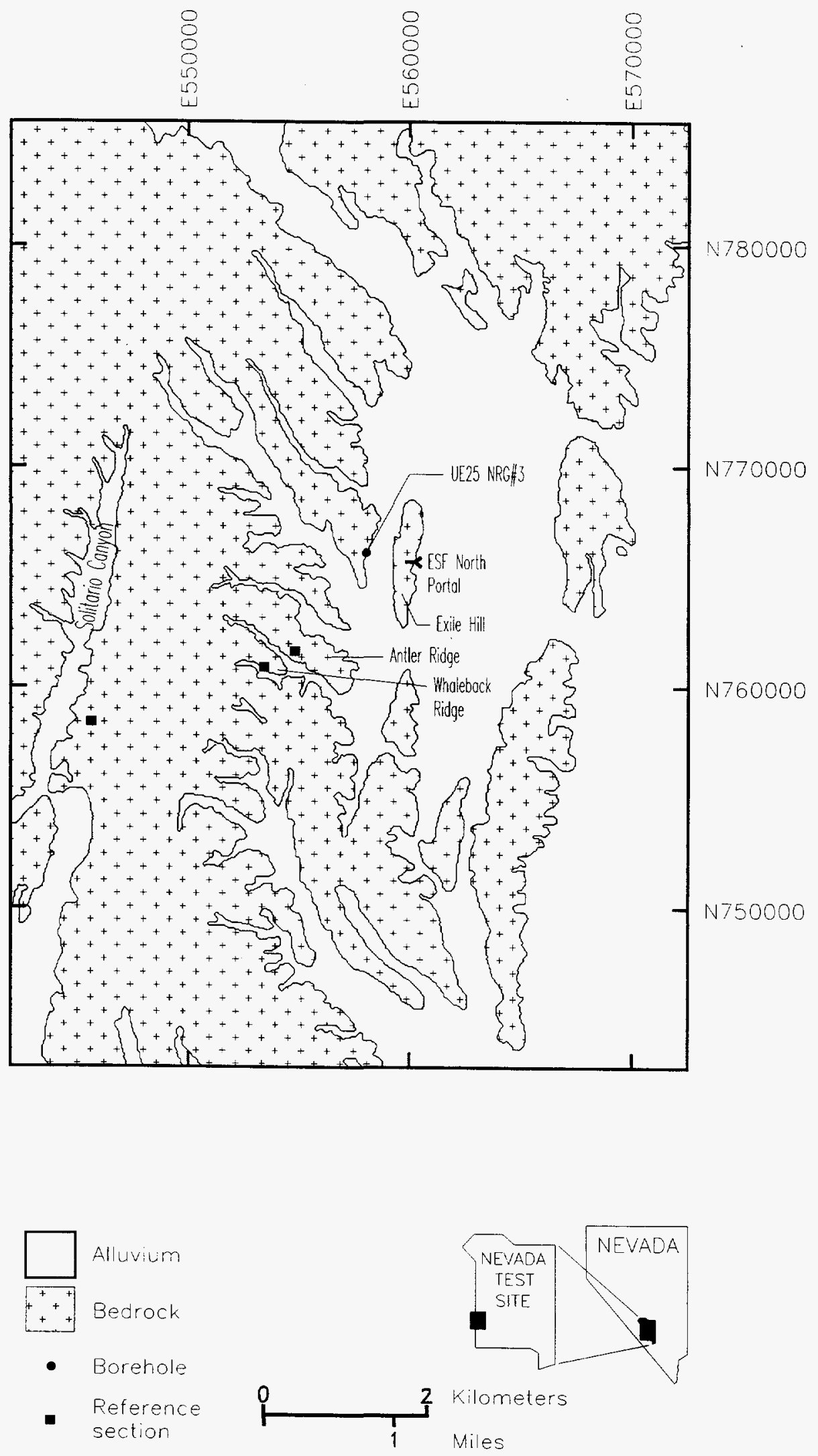

Figure 1. Location of drill hole UE-25 NRG\#3 and selected geographic features. The grid is the Nevada State Coordinate System. 
Table 1. Lithostratigraphic zonation of the Tiva Canyon Tuff in drill hole UE-25 NRG\#3 at Yucca Mountain, Nevada

[Depth, distance along the drill hole; Stratigraphic interval, true stratigraphic thickness; ft, feet]

\begin{tabular}{|c|c|c|c|}
\hline $\begin{array}{l}\text { Depth } \\
\text { (ft) }\end{array}$ & $\begin{array}{c}\text { Stratigraphic } \\
\text { interval } \\
\text { (ft) }\end{array}$ & Zone & Subzone \\
\hline $0-12.0$ & $0-8.2$ & \multirow{3}{*}{$\begin{array}{l}\text { CRYSTAL-RICH NONLITHOPHYSAL } \\
\text { ZONE (Tpcrn) }\end{array}$} & Pumice-poor subzone (Tpcrn3) \\
\hline $12.0-82.0$ & $8.2-54.8$ & & Mixed pumice subzone (Tpcrn2) \\
\hline $82.0-100.0$ & $54.8-66.8$ & & Crystal transition subzone (Tpcrn1) \\
\hline $100.0-188.0$ & $66.8-125.6$ & \multirow{3}{*}{$\begin{array}{l}\text { CRYSTAL-POOR UPPER } \\
\text { LITHOPHYSAL ZONE (Tpcpul) }\end{array}$} & \\
\hline $188.0-200.0$ & $125.6-133.6$ & & Spherulite-rich subzone (Tpcpul1) \\
\hline $200.0-206.7$ & $133.6-138.1$ & & \\
\hline $206.7-268.2$ & $138.1-179.2$ & \multicolumn{2}{|c|}{ CRYSTAL-POOR MIDDLE NONLITHOPHYSAL ZONE (Tpcpmn) } \\
\hline $268.2-330.0$ & $179.2-220.4$ & \multicolumn{2}{|c|}{ CRYSTAL-POOR LOWER LITHOPHYSAL ZONE (TpcplI) } \\
\hline
\end{tabular}

selected by Beth Widmann (SAIC) and April Walker (USGS). Duane Craft and Shannon Mahan (USGS) provided outstanding technical support in sample preparation and X-ray fluorescence analyses, respectively.

\section{STUDY METHODS}

Pieces of core approximately 3 in. long were split, and one-half was retained for reference in the Sample Management Facility at Jackass Flats near Yucca Mountain. The other one-half core was sampled, using a 0.5 -in-diameter diamond drill, to obtain two or three subsample cores approximately 1 to $1.5 \mathrm{in}$. long with emphasis on the rock matrix; lithic clasts and large pumice clasts were avoided as much as possible. These subsample cores were cleaned in distilled water, dried, and then pulverized to 200 -mesh powder in a hardened steel shatterbox. A representative split of approximately 3 to $5 \mathrm{~g}$ of the 200 -mesh rock powder was then analyzed for selected major and trace elements using a multi-target, energy-dispersive, X-ray fluorescence spectrometer. The USGS standard GSP-1 was analyzed with each set of 16 samples; the following coefficients of variation for the analyzed elements were obtained: $\mathrm{K}, \pm 1.2$ percent; $\mathrm{Ca}, \pm 3.7$ percent; $\mathrm{Ti}, \pm 2.4$ percent; $\mathrm{Rb}, \pm 1.4$ percent; $\mathrm{Sr}, \pm 1.3$ percent; $\mathrm{Y}, \pm 8.3$ percent; $\mathrm{Zr}, \pm 3.6$ percent; $\mathrm{Nb}, \pm 3.7$ percent; $\mathrm{Ba}, \pm 2.9$ percent; $\mathrm{La}, \pm 7.1$ percent; and $\mathrm{Ce}$, \pm 3.9 percent.

For the isotopic analyses, strontium was extracted from a split of the 200-mesh powder by digestion in concentrated $\mathrm{HF}$ and $\mathrm{H}_{2} \mathrm{SO}_{4}$. Strontium was purified by conventional ion-exchange chromatog- raphy, and isotope ratios were determined on a Finnigan MAT 262 thermal ionization mass spectrometer operating in a fully automatic static mode. Two samples of the USGS carbonate standard EN-1 were analyzed in each magazine of 15 samples. The mean ${ }^{87} \mathrm{Sr} /{ }^{86} \mathrm{Sr}$ of standard EN-1 was $0.70911 \pm 0.00001$ during the course of the analyses of the NRG\#3 samples. Mass fractionation during isotopic analyses was eliminated by normalizing the measured ${ }^{86} \mathrm{Sr} /{ }^{88} \mathrm{Sr}$ ratios to a value of 0.1194 and adjusting the ${ }^{87} \mathrm{Sr} /{ }^{86} \mathrm{Sr}$ ratios accordingly. The normalized ${ }^{87} \mathrm{Sr} /{ }^{86} \mathrm{Sr}$ values then were adjusted to a scale on which the value for standard EN-1 is 0.70920. Standard EN-1 was prepared from the shell of a modern Tridacna collected from Enewetok Lagoon in the western Pacific Ocean. Its contained $\mathrm{Sr}$ has the isotopic composition of ocean water. Uncertainties in the normalized and adjusted ${ }^{87} \mathrm{Sr} /{ }^{86} \mathrm{Sr}$ are better than \pm 0.01 percent at the 95 -percent confidence level.

\section{LITHOSTRATIGRAPHIC AND CHEMOSTRATIGRAPHIC FRAMEWORK}

The Tiva Canyon Tuff, the uppermost densely welded tuff of the Paintbrush Group of Miocene age, crops out extensively at Yucca Mountain (Scott and Bonk, 1984). The underlying, compositionally similar, but much thicker, Topopah Spring Tuff will be the host rock for construction of the potential repository. The Tiva Canyon and Topopah Spring Tuffs are internally zoned in their physical and chemical attributes including major and trace element composition, mineralogy, phenocryst type and content, degree of welding, and 
distribution of lithophysal cavities, pumice clasts, and lithic clasts (Lipman and others, 1966; Schuraytz and Vogel, 1989; Flood and others, 1989; Broxton and others, 1989; Farmer and others, 1991; Peterman and others, 1991; Singer and others, 1994). In both the Tiva Canyon and Topopah Spring Tuffs, crystal-poor highsilica rhyolite is overlain by crystal-rich rocks that are transitional in composition from high-silica rhyolite to quartz latite at the top of the unit (Flood and others, 1989; Schuraytz and Vogel, 1989). These compositional zones reflect gradients in the source magma that developed through crystal settling prior to eruption of the ash flows (Lipman and others, 1966; Smith, 1979), although the original magmatic compositions undoubtedly have been modified by eruptive, depositional, and post-depositional processes (Cas and Wright, 1993). Systematic Sr isotopic differences between the highsilica rhyolite and the quartz latite, and isotopic disequilibrium between phenocrysts and ground mass indicated that isotopic gradients (Noble and Hedge, 1969) accompanied the chemical zonations in the magma chambers (Lipman and others, 1966). More recent studies have shown similar neodymium (Nd) and lead $(\mathrm{Pb})$ isotopic variations (Hildreth, 1981; Johnson, 1989; Tegtmeyer and Farmer, 1990; Farmer and others, 1991). The isotopic zonation and the presence of older zircon in some tuffs indicate that assimilation of country rock as well as crystal settling produced the compositional gradients in the magmas (Johnson, 1989; Tegtmeyer and Farmer, 1990).

Reference sections have been established at Antler Ridge, Whaleback Ridge, and Solitario Canyon (fig. 1) to characterize the internal zonation of the Tiva Canyon Tuff on the basis of petrography and geochemistry and to correlate these features with the physical and mineralogical zonations used in outcrop mapping (Scott and Bonk, 1984). Chemical analyses have been completed on samples from these reference sections (USGS, unpub. data), and composite geochemical profiles are shown in figure 2 . The profiles were constructed by normalizing the stratigraphic positions of the samples to the contact between the crystal-rich and crystal-poor zones. Concentrations of most of the analyzed elements are uniform in the highsilica rhyolite (crystal-poor zone) as exemplified by $\mathrm{Ba}, \mathrm{Zr}$, and $\mathrm{Ti}$ (fig. 2). Rb displays considerably more scatter, which is probably the consequence of alkalielement mobility during late stage alteration and devitrification (Lipman, 1965). The elements $\mathrm{Zr}$ and $\mathrm{Ti}$ are remarkably uniform in the high-silica rhyolite with a variability that is commensurate solely with analytical uncertainty. The distribution of Ba shows more dispersion than $\mathrm{Ti}$ and $\mathrm{Zr}$ but is essentially invariant through the high-silica rhyolite. Rubidium displays considerable scatter in the high-silica rhyolite with a significant depletion in the lower part of the unit at the Solitario Canyon reference section. This zone also shows enrichment in ${ }^{18} \mathrm{O}$, which Marshall and others (in press) attribute to isotopic exchange attendant with hydration of the volcanic glass.

An important geochemical feature of the Tiva Canyon Tuff is the change in the pattern of element variation at the contact between the crystal-poor upper lithophysal zone and the superjacent crystal transition subzone (table 1, fig. 2). Above this contact, Ti, Zr, and $\mathrm{Ba}$ increase progressively upward through the crystalrich zone (fig. 2). The elements $\mathrm{La}, \mathrm{Ce}, \mathrm{Ca}, \mathrm{Sr}$, and $\mathrm{K}$ (not shown) also increase upward in this zone. The decrease in $\mathrm{Rb}$ upward (fig. 2) with the concomitant rise in $K$ results in a systematic increase in $K / R b$ ratios through the crystal-rich zone. For the Antler Ridge section, lines fit to the geochemical trends within the crystal-poor and crystal-rich zones intersect within 1 to 3 feet of the physical contact (Singer and others, 1994).

In outcrop, the crystal transition subzone corresponds in part to the lower part of the upper cliff map zone of Scott and Bonk (1984) which can be distinguished mineralogically from the subjacent high-silica rhyolite by the first appearance of biotite and plagioclase phenocrysts in the groundmass (Singer and others, 1994). The compositional gradation from highsilica rhyolite to quartz latite through much of the crystal-rich zone poses nomenclature problems in the assignment of specific rock names. Flood and others (1989), following Byers and others (1976), used the terms high-silica rhyolite for the crystal-poor zone and rhyolite and quartz latite for the crystal-rich zone. Using the representative analyses of Flood and others (1989) and trace element analyses of outcrop samples from the crystal-rich zone, Marshall and others (in press) concluded that the true quartz latite is characterized by Ba contents of 1,500 ppm or greater. Using this criterion, only the uppermost 9 to $12 \mathrm{ft}$ of the NRG\#3 section is quartz latite. Thus, all of the crystal transition zone and most of the pumice-poor subzone (table 1) are composed of the compositionally transitional rock types. The following rock terms will be used for convenience in the ensuing discussions: 

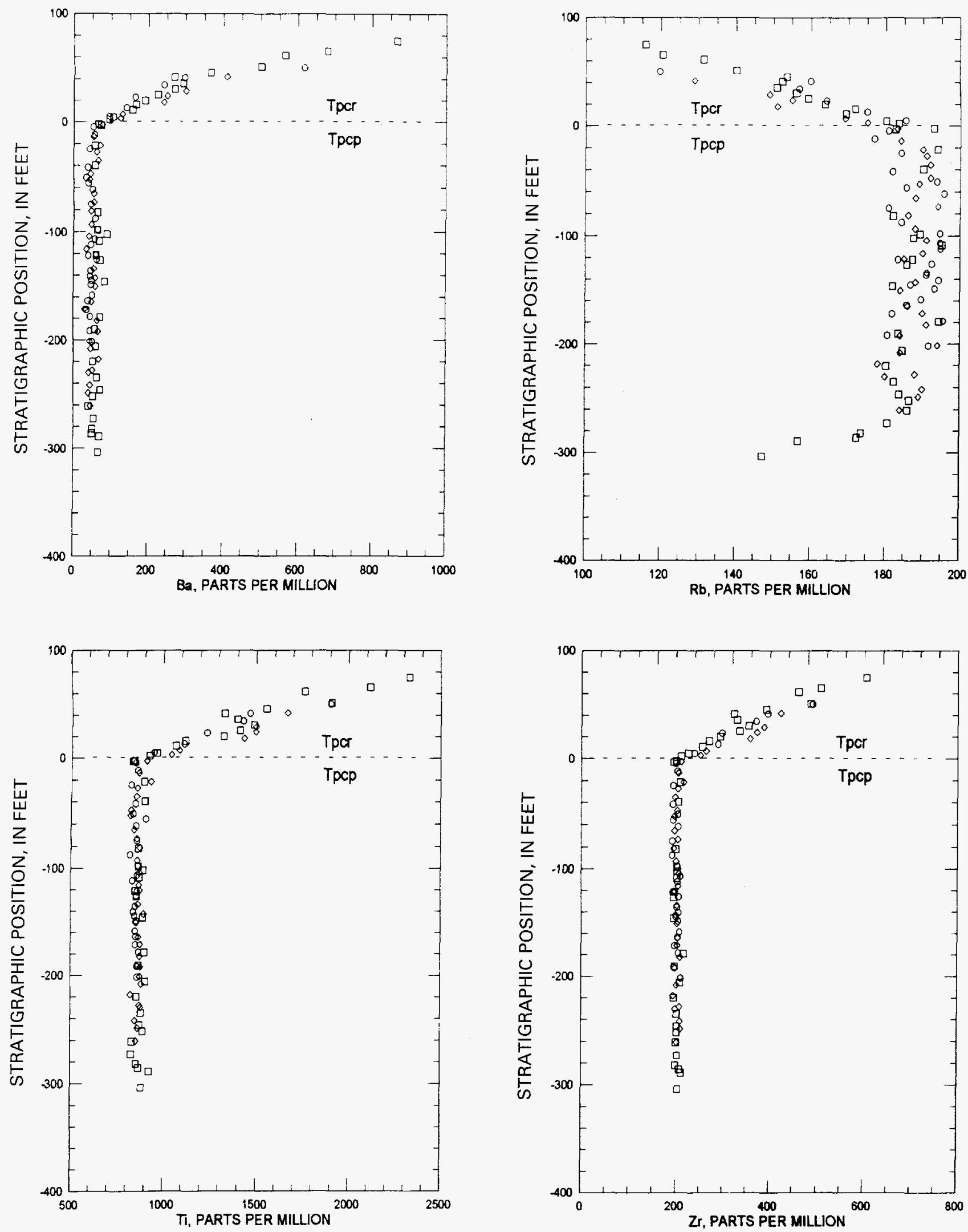

Figure 2. Composite geochemical profiles for samples from the Antler Ridge (circles), Whaleback Ridge (diamonds), and Solitario Canyon (squares) reference sections. (See table 2, footnote 2 for explanation of nomenclature.) 
(1) high-silica rhyolite (all of the crystal-poor zone),

(2) transitional quartz latite (crystal transition and mixed pumice subzones), and (3) quartz latite (pumice-poor subzone).

\section{GEOCHEMISTRY OF CORE SAMPLES FROM UE-25 NRG\#3}

Geochemical and Sr isotopic data for the Tiva Canyon Tuff intersected in drill hole UE-25 NRG\#3 are presented in table 2. Sample locations are given as positions along the axis of the drill hole and in true stratigraphic position relative to the collar of the drill hole. Stratigraphic positions (table 2 ) were calculated on the basis of the strike of beds of $022^{\circ}$ and a southeasterly dip of $15^{\circ}$ (D. Buesch, U.S. Geological Survey, written commun., 1994; Buesch and others, 1994) and by adjusting for the plunge and strike of the borehole $\left(56.5^{\circ}\right.$ at azimuth of $\left.95.2^{\circ}\right)$. The attitude of the bedding at the NRG\#3 drill pad is consistent with measurements made underground in the ESF of $018^{\circ}$ strike and $15^{\circ} \mathrm{SE}$ dip (Steve Beason, U.S. Bureau of Reclamation, oral commun., April 19, 1995). The zonal contacts identified along the borehole by Geslin and others (1995) were mathematically transposed to intercepts along the vertical and then converted to stratigraphic position based on the $15^{\circ}$ dip of the unit.

The remarkable uniformity of the high-silica rhyolite of the crystal-poor zone is illustrated by the means and standard deviations of elemental concentrations in the reference sections (table 3 ). Only in the lower vitric part of the unit have the compositions been modified significantly by post-depositional processes (fig. 2). Except for $\mathrm{Ba}$ and $\mathrm{Ca}$, mean element contents of the high-silica rhyolite in NRG\#3 (71.1 to $217.2 \mathrm{ft}$ ) are in agreement with the mean compositions of the reference sections (table 3 ). Zirconium and $\mathrm{Ti}$ are typically uniform throughout this unit in NRG\#3, but $\mathrm{Ba}$ is lower in most of high-silica rhyolite than in the reference sections, reaching comparable values only in the upper $30 \mathrm{ft}$ of the unit as shown by the inset in figure 3 . The stratigraphically lowest sample in the crystal-rich zone ( $66.8 \mathrm{ft}$, table 2 ) has significantly more $\mathrm{Ba}(89 \mathrm{ppm})$ than the highest sample $(71.1 \mathrm{ft})$ in the crystal-poor zone $(54 \mathrm{ppm})$. In the reference sections, Ba increases systematically and progressively upward from this contact (fig. 2), whereas Ba in NRG\#3 decreases at $64.7 \mathrm{ft}$ and then increases upward but with some minor reversals in trend (inset, fig. 3). Titanium and $\mathrm{Zr}$ also show similar reversals a few feet above the contact between the crystal-poor and crystalrich zones.

Except for some scatter in the lower part of the unit, $\mathrm{Ca}$ is relatively uniform throughout most of the high-silica rhyolite and increases progressively upward through the transitional quartz latite without notable reversals in trend (fig. 4). In the upper lithophysal subzone of the high-silica rhyolite, a linear increase in the middle part of the subzone is followed by a decrease in Sr up to the contact between crystal-poor and crystalrich zones. In contrast to $\mathrm{Ca}, \mathrm{Sr}$ displays systematic differences in concentrations among the lithostratigraphic zones of the high-silica rhyolite. Strontium appears to decrease in a stepwise fashion from the lower lithophysal, through the middle nonlithophysal to the upper lithophysal zones as illustrated by means and standard deviations of $30.6 \pm 3.3 \mathrm{ppm}$, $23.0 \pm 3.6 \mathrm{ppm}$, and $19.2 \pm 2.0 \mathrm{ppm}$, respectively (fig. 5). Immediately above the crystal-rich contact, $\mathrm{Sr}$ decreases and then increases systematically through the transitional quartz latite.

The rare-earth elements $\mathrm{La}$ and $\mathrm{Ce}$, scatter excessively throughout the high-silica rhyolite overall but define no particular trend throughout the unit (fig. 6). Both elements increase progressively upward through the crystal-rich zone. Cerium especially shows considerable scatter in the crystal transition subzone (Tpcrn1, fig. 6). The scatter of these elements in both the crystal-poor and crystal-rich zones is attributed to the fact that they are largely sequestered in trace accessory minerals such as allanite, perrierite, and sphene. Much larger subsamples of the tuff would likely reduce the scatter in these elements because the trace accessory minerals would be more adequately represented.

In contrast with most of the other elements, relatively uniform concentrations of $\mathrm{Nb}$ and $\mathrm{Rb}$ in the highsilica rhyolite are followed by decreases upward through the crystal-rich zone (fig. 7). Although generally decreasing, $\mathrm{Rb}$ shows appreciable scatter through crystal transition subzone (Tpcrn1, fig. 7) with no clear break in trend at the lower contact. The scatter of $\mathrm{Rb}$ in NRG\#3 is consistent with similar scatter observed in the reference sections (fig. 3), which in part derives from late-stage alkali mobility.

A decoupling of the alkalies $\mathrm{K}$ and $\mathrm{Rb}$ occurs in the crystal-rich zone where $\mathrm{K}$ increases markedly upward (fig. 8) whereas $\mathrm{Rb}$ decreases over the same stratigraphic interval. $\mathrm{K}$ and $\mathrm{Rb}$ are coherent in the high-silica rhyolite as shown by the nearly uniform $\mathrm{K} / \mathrm{Rb}$ ratios throughout the unit (fig. 9). Throughout 
Table 2. Geochemical and isotopic data for core samples from drill hole UE-25 NRG\#3, Yucca Mountain, Nevada

[ft, feet; \%, percent; ppm, parts per million; IR (Sr), initial ${ }^{87} \mathrm{Sr} /{ }^{86} \mathrm{Sr}$ ratio; ---, no analyses were done]

\begin{tabular}{|c|c|c|c|c|c|c|c|c|c|c|c|c|c|c|c|c|c|}
\hline $\begin{array}{l}\text { Sam- } \\
\text { ple } \\
\text { ID' }\end{array}$ & Zone $^{2}$ & $\begin{array}{l}\text { Depth } \\
\text { (ft) }\end{array}$ & $\begin{array}{l}\text { Strat. }^{3} \\
\text { (ft) }\end{array}$ & $\begin{array}{c}K \\
(\%)\end{array}$ & $\begin{array}{c}\mathrm{Ca} \\
(\%)\end{array}$ & $\begin{array}{c}\mathrm{Ti} \\
(\%)\end{array}$ & $\begin{array}{c}\mathbf{R b} \\
(\mathrm{ppm})\end{array}$ & $\begin{array}{c}\mathrm{Sr} \\
(\mathrm{ppm})\end{array}$ & $\begin{array}{c}Y \\
(p p m)\end{array}$ & $\underset{\text { (ppm) }}{\mathrm{Zr}}$ & $\begin{array}{c}\mathrm{Nb} \\
(\mathrm{ppm})\end{array}$ & $\begin{array}{c}\text { Ba } \\
(\mathbf{p p m})\end{array}$ & $\underset{\text { (ppm) }}{\text { La }}$ & $\begin{array}{c}\mathrm{Ce} \\
(\mathrm{ppm})\end{array}$ & ${ }^{87} \mathrm{Rb} \mathrm{b}^{86} \mathrm{Sr}$ & ${ }^{87} \mathrm{Sr} /{ }^{86} \mathrm{Sr}$ & IR (Sr) \\
\hline 30105 & Tpcrn3 & $8.4-8.5$ & 5.6 & 4.97 & 0.832 & 3157 & 86 & 199 & 40 & 785 & 12 & 2289 & 223 & 394 & 1.25 & 0.70922 & 0.70899 \\
\hline 29772 & Tpcrn2 & $13.4-13.7$ & 9.1 & 4.97 & 0.787 & 3004 & 89 & 194 & 39 & 763 & 13 & 2182 & 232 & 388 & --- & -. & $\cdots$ \\
\hline 29773 & Tpcrn2 & $19.1-19.4$ & 12.9 & 4.66 & 0.653 & 2642 & 98 & 104 & 41 & 637 & 16 & 1058 & 191 & 314 & 2.73 & 0.71022 & 0.70973 \\
\hline 29774 & Tpcrn2 & $24.2-24.5$ & 16.3 & 4.71 & 0.506 & 2513 & 108 & 106 & 40 & 613 & 15 & 1090 & 196 & 322 & -- & --- & $-\cdots$ \\
\hline 29775 & Tpcrn2 & $36.9-37.1$ & 24.7 & 4.63 & 0.526 & 2386 & 112 & 99 & 40 & 611 & 18 & 868 & 186 & 308 & -- & --- & --- \\
\hline 29776 & Tpcrn2 & $42.3-42.6$ & 28.4 & 4.73 & 0.472 & 2328 & 120 & 96 & 42 & 576 & 18 & 794 & 175 & 294 & 3.62 & 0.71085 & 0.71020 \\
\hline 29777 & Tpcrn2 & $48.6-48.9$ & 32.8 & 4.43 & 0.442 & 1928 & 142 & 68 & 40 & 488 & 19 & 567 & 159 & 252 & 6.04 & 0.71140 & 0.71031 \\
\hline 29778 & Tpcrn2 & $54.9-55.3$ & 36.8 & 4.42 & 0.467 & 1897 & 131 & 67 & 44 & 500 & 20 & 533 & 150 & 243 & --- & --- & -- \\
\hline 29779 & Tpcrnl & $82.0-82.3$ & 54.9 & 3.93 & 0.352 & 1338 & 163 & 59 & 41 & 342 & 25 & 490 & 92 & 163 & 8.00 & 0.71208 & 0.71064 \\
\hline 29780 & Tpcrn1 & $86.3-86.5$ & 57.7 & 3.94 & 0.324 & 1336 & 160 & 44 & 43 & 331 & 25 & 231 & 92 & 141 & 10.53 & 0.71306 & 0.71116 \\
\hline 35121 & Tpcrn1 & $88.5-88.7$ & 59.2 & 3.77 & 0.289 & 1027 & 194 & 33 & 42 & 249 & 32 & 110 & 53 & 73 & --- & --- & -- \\
\hline 29781 & Tpcrnl & $88.8-89.0$ & 59.4 & 3.67 & 0.225 & 1026 & 189 & 33 & 43 & 243 & 32 & 103 & 48 & 83 & 16.58 & 0.71492 & 0.71193 \\
\hline 35122 & Tpcrnl & $89.0-89.4$ & 59.6 & 3.59 & 0.247 & 1033 & 171 & 36 & 39 & 239 & 32 & 143 & 57 & 96 & -- & --- & --- \\
\hline 36237 & Tpcrn1 & $89.7-89.9$ & 60.0 & 3.67 & 0.235 & 1065 & 186 & 35 & 37 & 258 & 28 & 136 & 46 & 87 & --- & $\cdots$ & $\cdots$ \\
\hline 35123 & Tpern1 & $91.8-92.0$ & 61.4 & 3.55 & 0.204 & 967 & 184 & 25 & 43 & 229 & 30 & 94 & 46 & 79 & $\ldots$ & --- & --- \\
\hline 30106 & Tpcrn1 & $92.2-92.5$ & 61.7 & 3.60 & 0.195 & 968 & 186 & 28 & 40 & 227 & 29 & 80 & 45 & 78 & 19.23 & 0.71533 & 0.71186 \\
\hline 36236 & Tpcrn1 & $93.7-93.8$ & 62.6 & 3.55 & 0.205 & 897 & 191 & 24 & 36 & 223 & 29 & 89 & 42 & 70 & --- & --- & --- \\
\hline 35124 & Tpcrn1 & $96.0-96.3$ & 64.2 & 3.51 & 0.175 & 833 & 182 & 15 & 39 & 200 & 29 & 58 & 42 & 73 & --- & --- & -- \\
\hline 35125 & Tpcrn1 & $96.8-96.9$ & 64.7 & 3.47 & 0.177 & 885 & 185 & 16 & 35 & 198 & 31 & 67 & 46 & 83 & -- & -- & $\cdots$ \\
\hline 29782 & Tpcrn1 & $99.6-99.9$ & 66.6 & 3.58 & 0.165 & 866 & 189 & 18 & 43 & 205 & 31 & 44 & 35 & 64 & 30.41 & 0.71715 & 0.71166 \\
\hline 35126 & Tpcrn1 & $99.9-100.2$ & 66.8 & 3.48 & 0.165 & 877 & 189 & 20 & 36 & 197 & 32 & 89 & 45 & 72 & -- & -- & -- \\
\hline 29783 & Tpcpul & $106.4-106.6$ & 71.1 & 3.55 & 0.169 & 881 & 186 & 17 & 45 & 211 & 34 & 54 & 47 & 74 & 31.69 & 0.71722 & 0.71150 \\
\hline 29784 & Tpcpul & $115.2-115.5$ & 77.1 & 3.61 & 0.174 & 900 & 188 & 16 & 38 & 207 & 31 & 44 & 43 & 61 & $\cdots$ & $\cdots$ & --- \\
\hline 29785 & Tpcpul & $123.7-124.0$ & 82.7 & 3.62 & 0.199 & 872 & 188 & 22 & 36 & 206 & 30 & 54 & 49 & 98 & --- & -- & --- \\
\hline 29786 & Tpcpul & $138.5-138.9$ & 92.7 & 3.63 & 0.188 & 883 & 195 & 20 & 34 & 225 & 31 & 42 & 33 & 91 & -- & $-\cdots$ & $\cdots$ \\
\hline 29787 & Tpcpul & $145.0-145.3$ & 97.0 & 3.54 & 0.181 & 895 & 196 & 20 & 42 & 214 & 31 & 42 & 35 & 50 & 28.38 & 0.71669 & 0.71157 \\
\hline 29788 & Tpcpul & $152.4-152.7$ & 103.6 & 3.58 & 0.178 & 859 & 200 & 21 & 38 & 204 & 31 & 19 & 38 & 57 & -- &.-- & $\cdots$ \\
\hline 29789 & Tpcpul & $160.0-160.3$ & 107.0 & 3.54 & 0.173 & 879 & 191 & 19 & 60 & 198 & 32 & 24 & 40 & 61 & --- & -- & $\cdots$ \\
\hline 30110 & Tpcpul & $177.9-178.2$ & 118.9 & 3.57 & 0.161 & 853 & 189 & 17 & 40 & 198 & 32 & 23 & 41 & 70 & -- & --- & -- \\
\hline 29790 & Tpcpul & $185.1-185.4$ & 123.7 & 3.79 & 0.177 & 846 & 192 & 21 & 42 & 202 & 32 & 35 & 37 & 67 & $-\cdots$ & $-\cdots$ & $\ldots$ \\
\hline 29791 & Tpcpul & $192.5-192.8$ & 128.7 & 3.71 & 0.180 & 858 & 188 & 17 & 38 & 198 & 32 & 19 & 39 & 69 & 32.03 & 0.71757 & 0.71179 \\
\hline 30107 & Tpcpul & 203.3-203.6 & 135.9 & 3.63 & 0.175 & 830 & 189 & 17 & 37 & 194 & 31 & 31 & 52 & 75 & --- & --- & $\cdots$ \\
\hline 29792 & Tpcpmn & $206.9-207.3$ & 138.3 & 3.60 & 0.177 & 835 & 190 & 16 & 39 & 202 & 33 & 20 & 38 & 74 & --- & $-\cdots$ & -- \\
\hline 29793 & Tpcpmn & $212.9-213.1$ & 142.3 & 3.57 & 0.181 & 867 & 193 & 25 & 42 & 204 & 38 & 28 & 56 & 74 & --- & -.- & -- \\
\hline 29794 & Tpcpmn & $220.1-220.4$ & 147.1 & 3.61 & 0.171 & 866 & 197 & 24 & 40 & 197 & 32 & 24 & 37 & 69 & $\cdots$ & --- & $--\cdot$ \\
\hline 29795 & Tpcpmn & $227.6-227.9$ & 152.1 & 3.58 & 0.176 & 871 & 189 & 22 & 48 & 200 & 32 & 33 & 56 & 62 & $-\cdots$ & $\cdots$ & $\cdots$ \\
\hline
\end{tabular}


Table 2. Geochemical and isotopic data for core samples from drill hole UE-25 NRG\#3, Yucca Mountain, Nevada---Continued

\begin{tabular}{|c|c|c|c|c|c|c|c|c|c|c|c|c|c|c|c|c|c|}
\hline $\begin{array}{c}\text { Sam- } \\
\text { ple } \\
\text { ID' }\end{array}$ & $Z_{\text {Zne }}^{2}$ & $\begin{array}{l}\text { Depth } \\
\text { (ft) }\end{array}$ & $\begin{array}{c}\text { Strat. }^{3} \\
\text { (ft) }\end{array}$ & $\begin{array}{c}K \\
(\%)\end{array}$ & $\begin{array}{c}\mathrm{Ca} \\
(\%)\end{array}$ & $\begin{array}{c}\mathrm{Ti} \\
(\%)\end{array}$ & $\begin{array}{c}\text { Rb } \\
\text { (ppm) }\end{array}$ & $\underset{(\mathbf{p p m})}{\mathrm{Sr}}$ & $\underset{(p p m)}{Y}$ & $\underset{\text { (ppm) }}{\mathrm{Zr}}$ & $\begin{array}{c}\text { Nb } \\
\text { (ppm) }\end{array}$ & $\begin{array}{c}\mathrm{Ba} \\
(\mathrm{ppm})\end{array}$ & $\underset{(p p m)}{\text { La }}$ & $\underset{(\mathrm{ppm})}{\mathrm{Ce}}$ & ${ }^{87} \mathrm{Rb} /{ }^{86} \mathrm{Sr}$ & ${ }^{87} \mathrm{Sr}{ }^{\beta 6} \mathrm{Sr}$ & IR (Sr) \\
\hline 29796 & Tpcpmn & $235.4-235.9$ & 157.4 & 3.62 & 0.186 & 873 & 194 & 23 & 38 & 203 & 34 & 25 & 37 & 80 & -- & $\cdots$ & -- \\
\hline 29797 & Tpcpmn & $243.9-244.2$ & 163.0 & 3.56 & 0.167 & 894 & 192 & 22 & 46 & 211 & 33 & 26 & 44 & 59 & $\ldots$ & $\cdots$ & --- \\
\hline 29798 & Tpcpmn & $253.3-253.4$ & 169.2 & 3.60 & 0.163 & 866 & 193 & 25 & 41 & 204 & 32 & 32 & 42 & 80 & -- & --- & --- \\
\hline 29799 & Tpcpmn & $260.3-260.6$ & 174.0 & 3.63 & 0.167 & 875 & 193 & 20 & 48 & 201 & 33 & 23 & 53 & 68 & 27.94 & 0.71651 & 0.71147 \\
\hline 30108 & Tpcpmn & $267.1-267.4$ & 178.5 & 3.63 & 0.187 & 884 & 189 & 30 & 42 & 201 & 33 & 23 & 45 & 65 & --- & $\cdots$ & --- \\
\hline 29800 & Tpcpll & $274.5-274.5$ & 183.5 & 3.63 & 0.171 & 885 & 190 & 34 & 38 & 204 & 32 & 28 & 45 & 61 & --- & -- & --. \\
\hline 29801 & Tpcpll & $280.3-280.6$ & 187.3 & 3.61 & 0.173 & 868 & 192 & 30 & 38 & 202 & 33 & 24 & 37 & 74 & -- & $\cdots$ & --- \\
\hline 29802 & Tpcpll & $286.2-286.5$ & 191.3 & 3.57 & 0.177 & 868 & 185 & 27 & 38 & 201 & 31 & 24 & 49 & 75 & --- & $\cdots$ & --- \\
\hline 30111 & Tpcpll & $293.0-293.2$ & 195.8 & 3.57 & 0.240 & 872 & 186 & 26 & 40 & 203 & 32 & 25 & 41 & 74 & $\cdots$ & -- & --- \\
\hline 30109 & Tpcpll & $300.0-300.3$ & 200.5 & 3.59 & 0.175 & 883 & 190 & 31 & 31 & 204 & 34 & 27 & 30 & 70 & --- & $\cdots$ & --- \\
\hline 29803 & Tpcpll & $310.2-310.5$ & 207.3 & 3.56 & 0.216 & 898 & 189 & 30 & 39 & 200 & 31 & 26 & 42 & 77 & $-\cdots$ & --- & --- \\
\hline 29804 & Tpcpll & $321.4-321.7$ & 214.8 & 3.58 & 0.165 & 863 & 191 & 27 & 37 & 200 & 31 & 29 & 46 & 74 & $\cdots$ & $\ldots$ & -- \\
\hline 29805 & Tpcpll & $325.1-325.3$ & 217.2 & 3.59 & 0.172 & 881 & 192 & 35 & 42 & 205 & 32 & 23 & 38 & 76 & 15.88 & 0.71516 & 0.71229 \\
\hline
\end{tabular}

'Sample ID: These are the last five digits of the bar-code numbers, which are prefixed by SPCO00.

${ }^{2}$ Zones: Tpc refers to Tertiary, Paintbrush Canyon Group, Tiva Canyon Tuff. Suffix letters identify internal zonal features: $\mathrm{m} 3$, pumice-poor subzone of the crystal-rich nonlithophysal zone; rn2, mixed pumice subzone of the crystal-rich nonlithophysal zone; rn1, crystal transition subzone of the crystal-rich nonlithophysal zone; pul, crystal-poor upper lilthophysal zone; pmn, crystal-poor middle nonlithophysal zone; and pll, crystal-poor lower lithophysal zone.

${ }^{3}$ Strat:: Designates the true stratigraphic position of the sample, taking into account the strike and dip of the unit and the plunge and azimuth of the borehole. The stratigraphic position is calculated from midpoint of the core sample interval.

Table 3. Mean compositions of the high-silica rhyolite of the Tiva Canyon Tuff, Yucca Mountain, Nevada

[n, number of analyses used to determine the mean and standard deviation (sigma); \%, percent; ppm, parts per million]

\begin{tabular}{|c|c|c|c|c|c|c|c|c|}
\hline \multirow{3}{*}{ Element } & \multicolumn{6}{|c|}{ Reference section } & & \\
\hline & \multicolumn{2}{|c|}{$\begin{array}{c}\text { Solitario Canyon } \\
n=24\end{array}$} & \multicolumn{2}{|c|}{$\begin{array}{c}\text { Whaleback Ridge } \\
n=26\end{array}$} & \multicolumn{2}{|c|}{$\begin{array}{c}\text { Antler Ridge } \\
n=25\end{array}$} & \multicolumn{2}{|c|}{$\begin{array}{c}\text { UE-25 NRG\#3 } \\
n=29\end{array}$} \\
\hline & Mean & Sigma & Mean & Sigma & Mean & Sigma & Mean & Sigma \\
\hline $\bar{K}(\%)$ & 3.60 & 0.17 & 3.56 & 0.04 & 3.63 & 0.08 & 3.60 & 0.05 \\
\hline $\mathrm{Ca}(\%)$ & 0.41 & 0.20 & 0.50 & 0.26 & 0.66 & 0.26 & 0.18 & 0.02 \\
\hline $\mathrm{Ti}(\mathrm{ppm})$ & 870 & 24 & 863 & 17.8 & 853 & 16.0 & 872 & 16.6 \\
\hline $\mathrm{Rb}(\mathrm{ppm})$ & 187 & 4.6 & 188 & 3.9 & 188 & 5.6 & 191 & 3.3 \\
\hline $\mathrm{Sr}(\mathrm{ppm})$ & 17 & 4.2 & 19 & 5.1 & 19 & 4.2 & 24 & 5.7 \\
\hline $\mathrm{Y}(\mathrm{ppm})$ & 39 & 1.8 & 42 & 4.7 & 44 & 3.4 & 41 & 5.2 \\
\hline $\mathrm{Zr}(\mathrm{ppm})$ & 202 & 5.2 & 202 & 4.5 & 201 & 5.5 & 204 & 5.8 \\
\hline $\mathrm{Nb}$ (ppm) & 32 & 1.3 & 32 & 1.1 & 31 & 1.0 & 32 & 1.5 \\
\hline $\mathrm{Ba}(\mathrm{ppm})$ & 64 & 11.3 & 51 & 9.9 & 48 & 8.1 & 30 & 9.4 \\
\hline $\mathrm{La}(\mathrm{ppm})$ & 47 & 5.3 & 43 & 5.3 & 43 & 5.5 & 42 & 6.7 \\
\hline $\mathrm{Ce}(\mathrm{ppm})$ & 77 & 5.6 & 73 & 6.8 & 74 & 6.5 & 71 & 9.4 \\
\hline
\end{tabular}




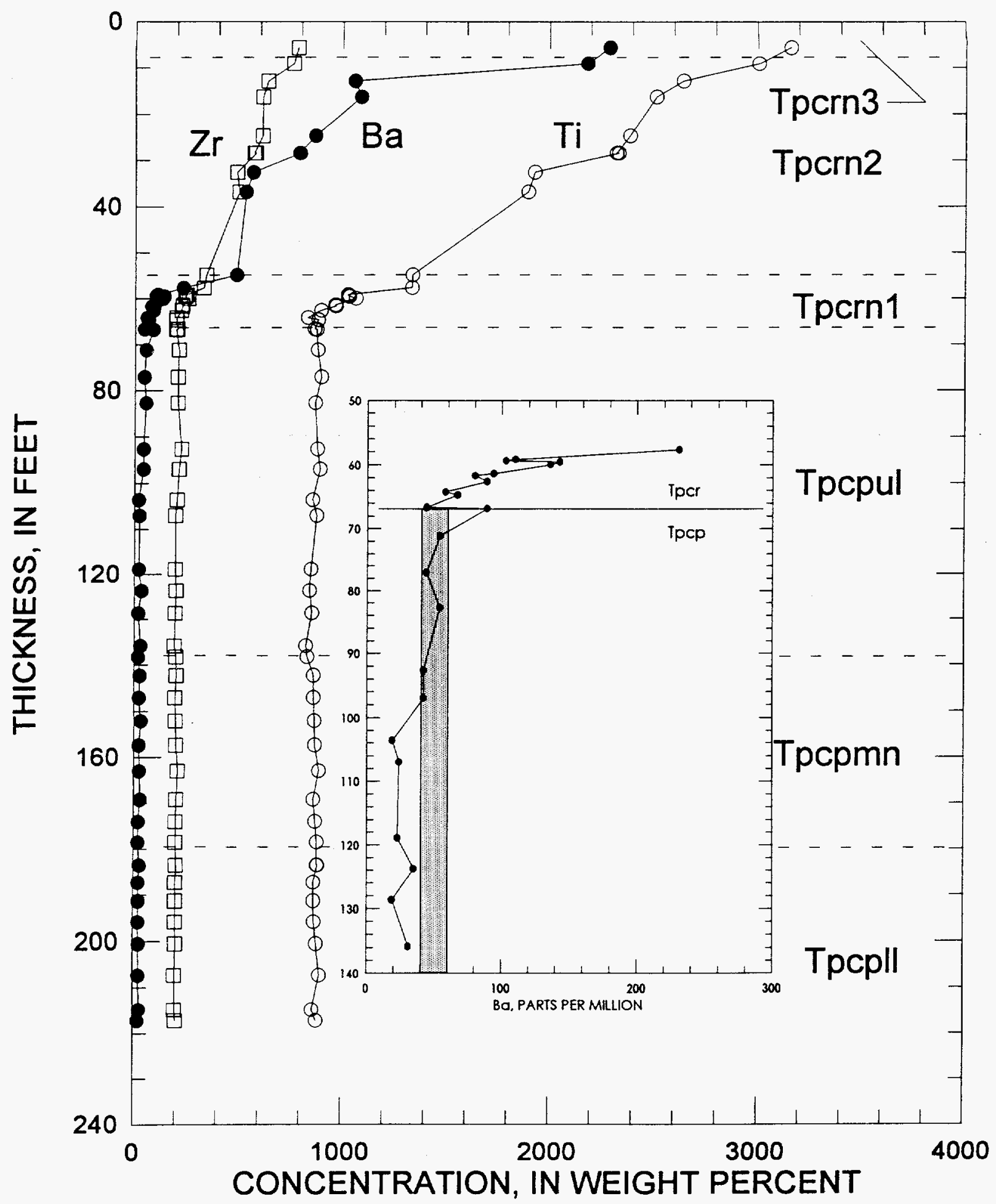

Figure 3. Concentrations of $\mathrm{Ti}, \mathrm{Zr}$, and $\mathrm{Ba}$ in samples of the Tiva Canyon Tuff from drill hole UE-25 NRG\#3. The inset shows the distribution of $\mathrm{Ba}$ in the upper part of the crystal-poor zone and the lower part of the crystal-rich zone. The shaded vertical rectangle represents the mean concentration of $\mathrm{Ba}$ in the reference sections; the width is approximately defined by two standard deviations (table 3 ). 


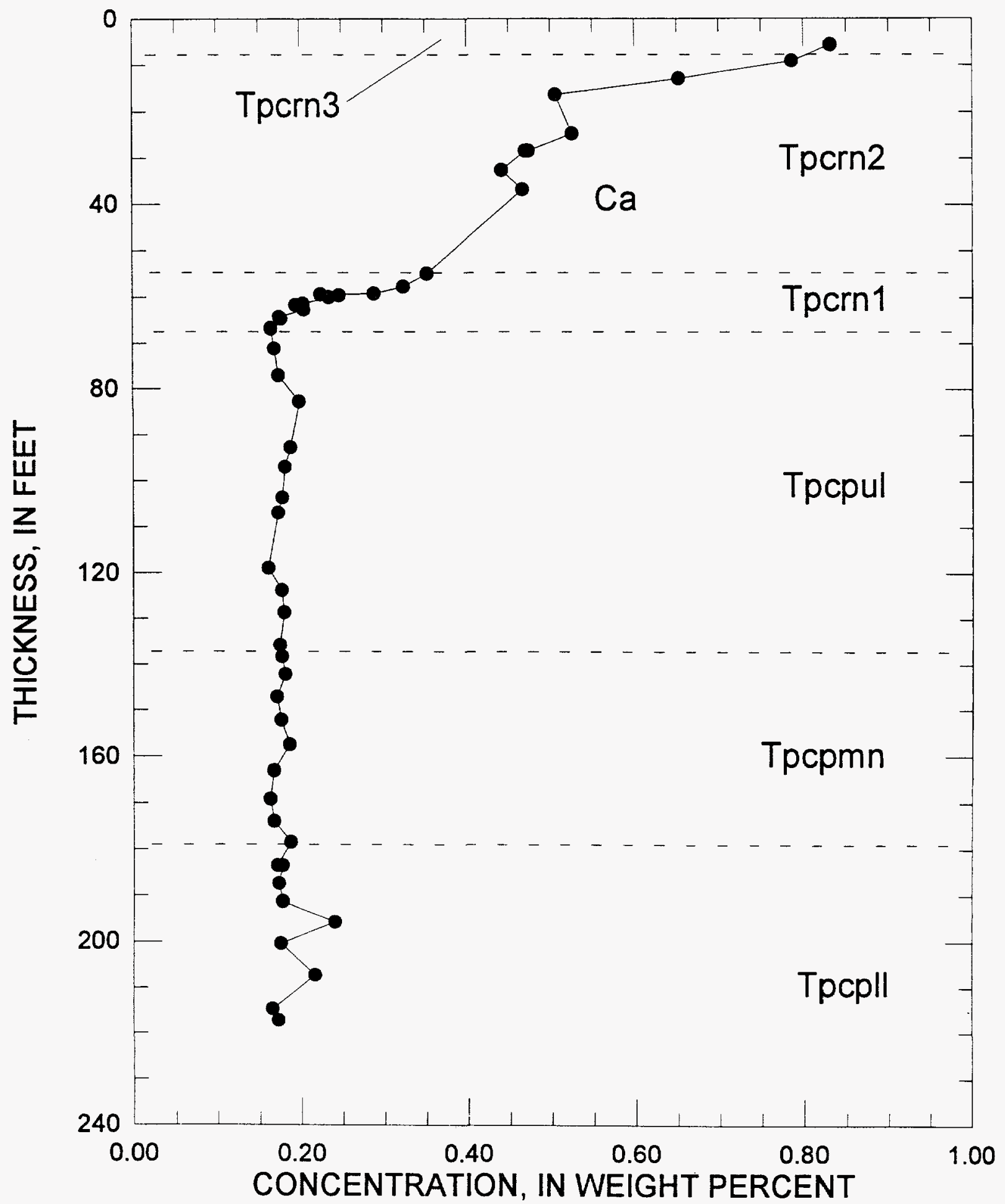

Figure 4. Concentration of $\mathrm{Ca}$ in samples of the Tiva Canyon Tuff from drill hole UE-25 NRG\#3. 


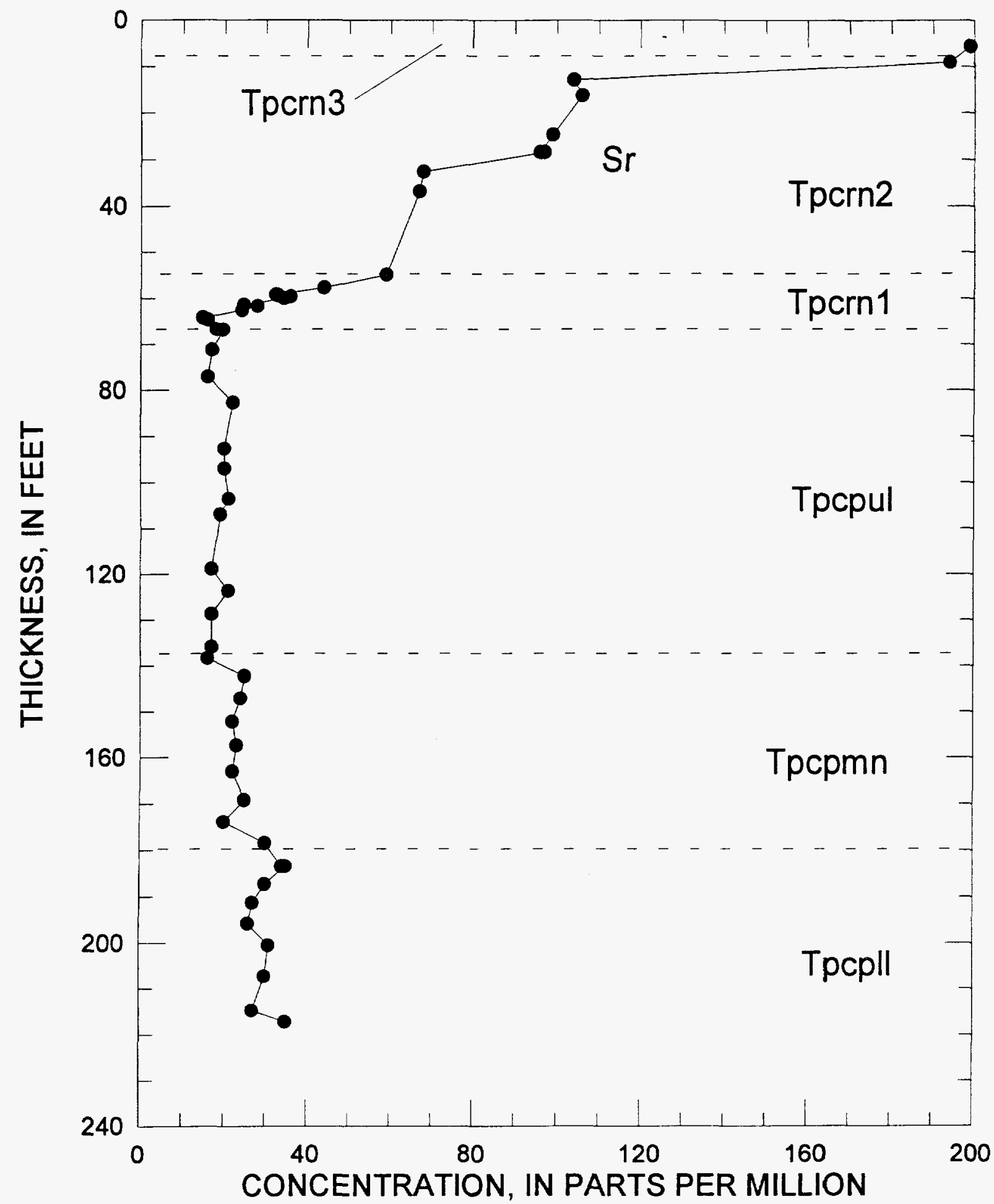

Figure 5. Concentration of $\mathrm{Sr}$ in samples of the Tiva Canyon Tuff from drill hole UE-25 NRG\#3. 


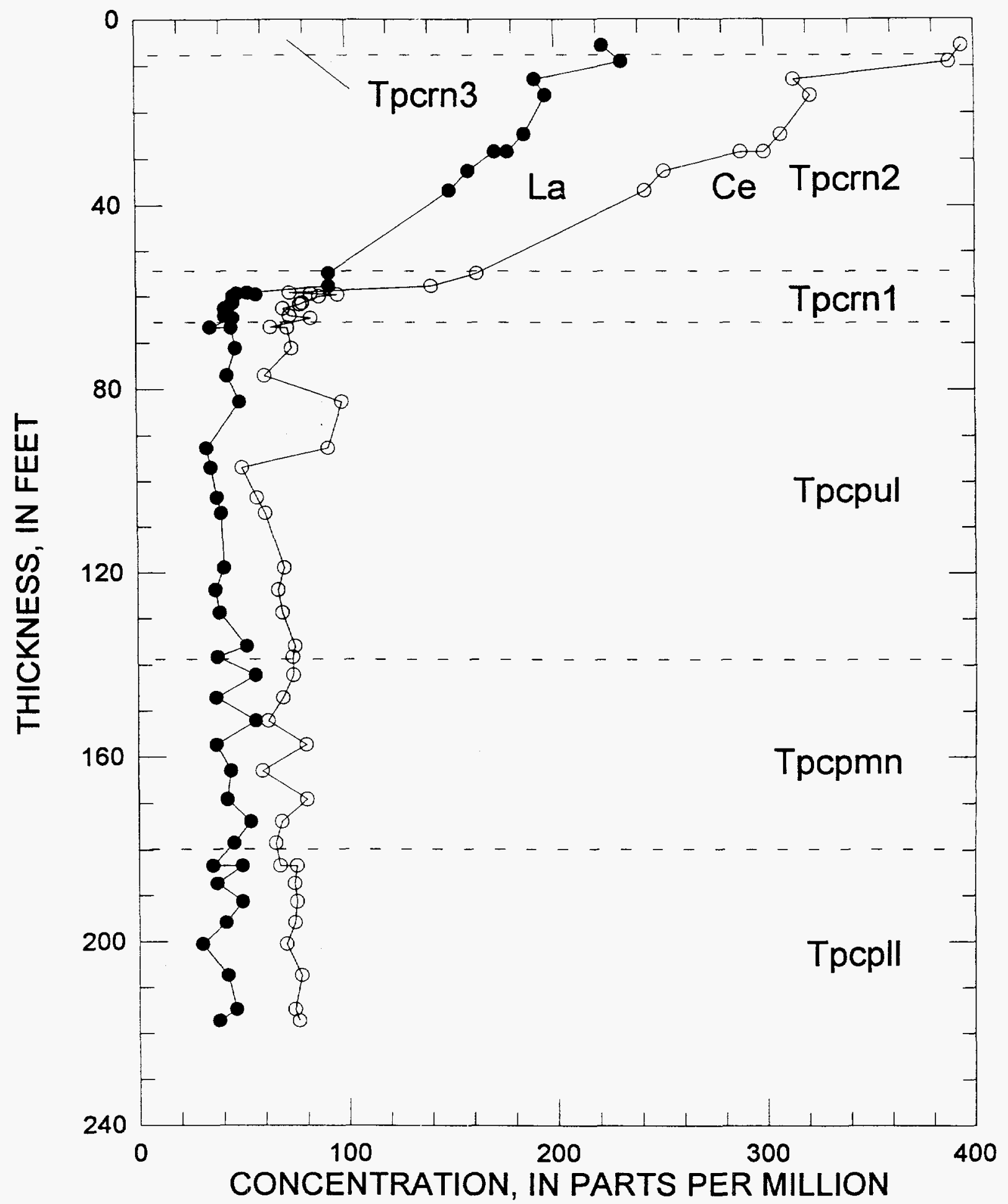

Figure 6. Concentrations of $L a$ and $C e$ in samples of the Tiva Canyon Tuff from drill hole UE-25 NRG\#3. 


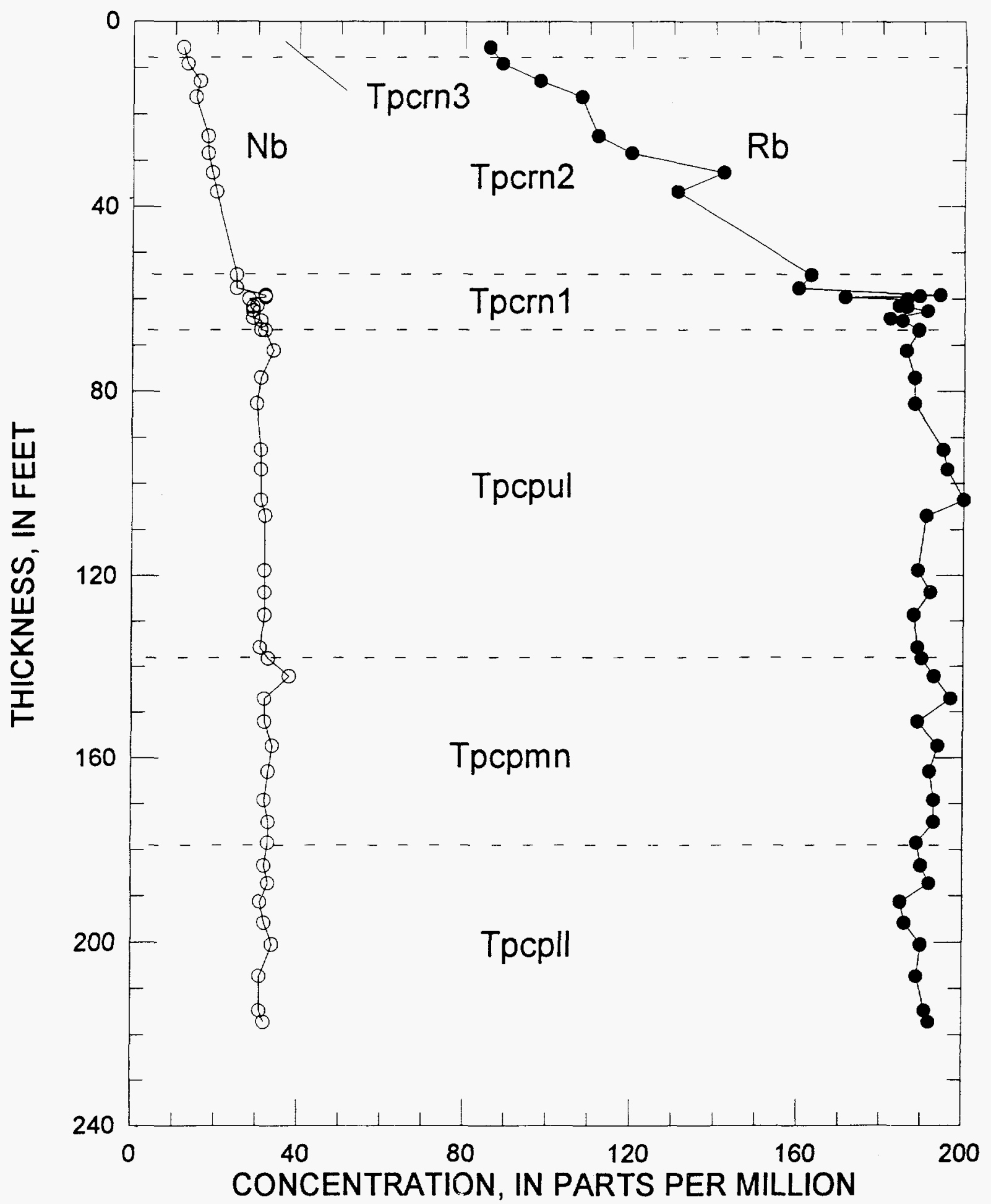

Figure 7. Concentrations of $\mathrm{Nb}$ and $\mathrm{Rb}$ in samples of the Tiva Canyon Tuff from drill hole UE-25 NRG\#3. 


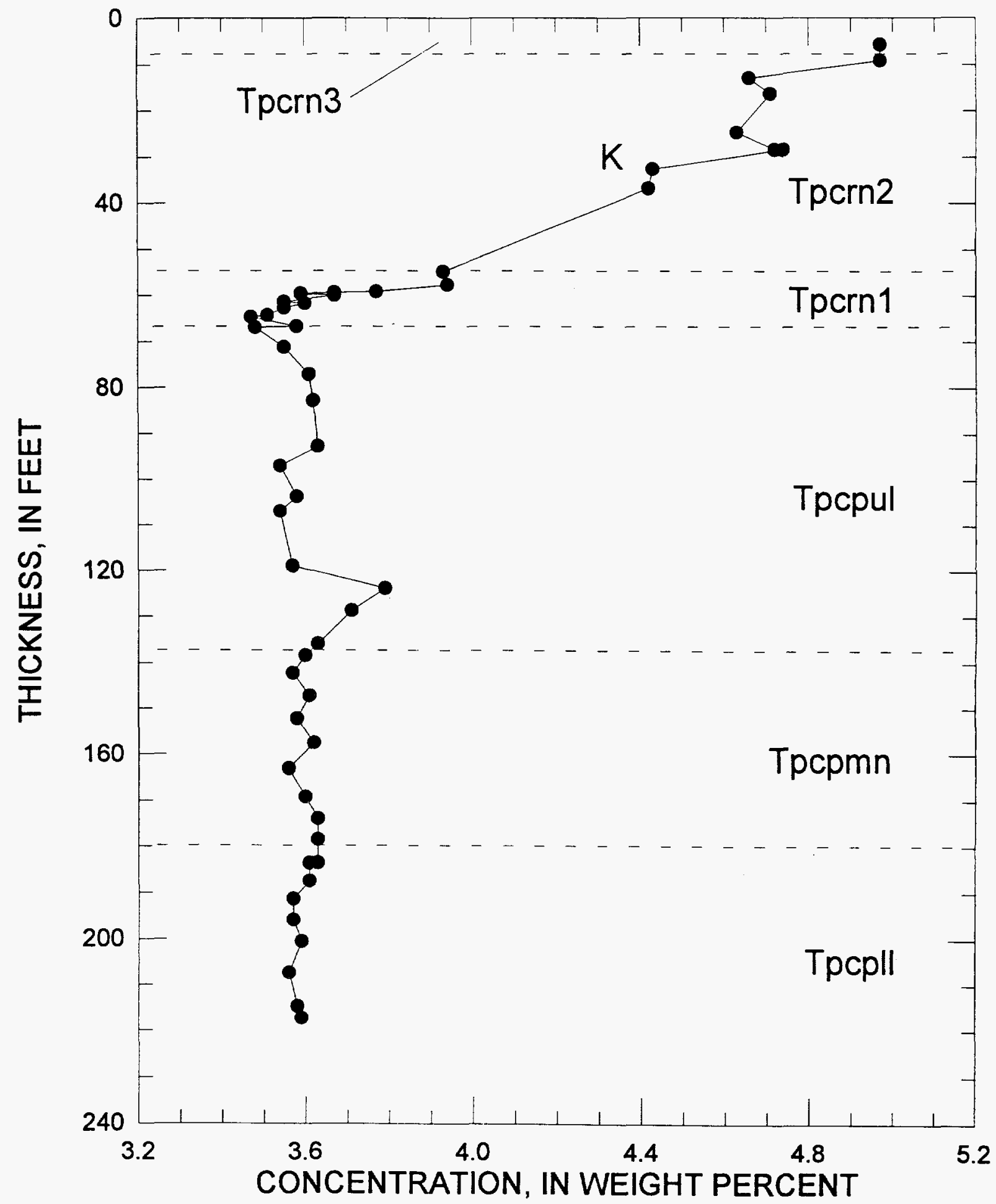

Figure 8. Concentrations of $K$ in samples of the Tiva Canyon Tuff from drill hole UE-25 NRG\#3. 


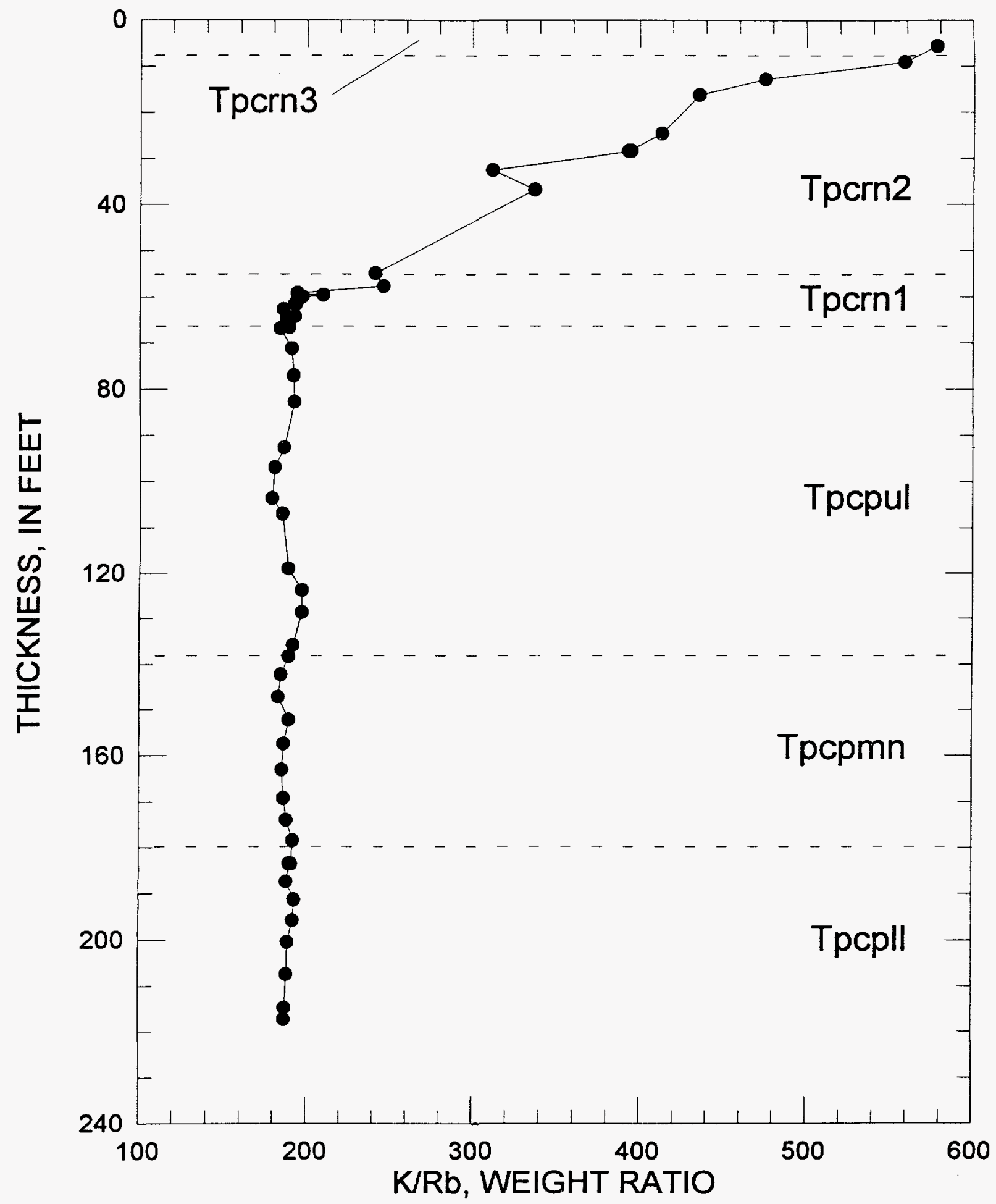

Figure 9. Variations of K/Rb ratio in samples of the Tiva Canyon Tuff from drill hole UE-25 NRG\#3. 
the unit, $\mathrm{K} / \mathrm{Rb}$ ratios range from a mean of about 190 in the high-silica rhyolite to nearly 600 in the quartz latite of the pumice-poor subzone of the crystal-rich zone (table 1).

The strontium isotopic composition of the Tiva Canyon Tuff also varies systematically throughout the unit (fig. 10). The curve labelled "Present-day ratio" is defined by the measured ${ }^{87} \mathrm{Sr} /{ }^{86} \mathrm{Sr}$ ratios of the samples whereas the curve designated "Initial ratios" is the calculated initial ${ }^{87} \mathrm{Sr} /{ }^{86} \mathrm{Sr}$ ratios [IR (Sr)] assuming closed-system evolution from the depositional age of $12.7 \mathrm{Ma}$. The initial ratios for the high-silica rhyolite show limited variability with a mean of 0.7117 . Unlike most of the geochemical trends, the IR(Sr) values do not change abruptly at the contact between the crystalpoor and crystal-rich zones but continue unchanged well into the crystal transition subzone followed by a sharp decrease to 0.7090 through the transitional quartz latite. These $\mathrm{Sr}$-isotope variations are similar to those reported for bulk rock and sanidine samples of the Tiva Canyon Tuff by Farmer and others (1991).

In figure 11, data for a representative suite of samples of transitional quartz latite and quartz latite from NRG\#3 have been normalized to the mean highsilica rhyolite (table 3). For each sample, element concentrations of individual samples are divided by the corresponding mean element concentrations of the high-silica rhyolite. The diagram emphasizes the progressive upward depletion in $\mathrm{Rb}$ and $\mathrm{Nb}$, the remarkably constant $Y$, and the progressive enrichment in $K$, $\mathrm{Ca}, \mathrm{Ti}, \mathrm{Sr}, \mathrm{Zr}, \mathrm{Ba}, \mathrm{La}$, and $\mathrm{Ce}$ relative to the high-silica rhyolite.

The foregoing discussion emphasizes the geochemical similarity of the Tiva Canyon Tuff in NRG\#3 with the samples from the Solitario Canyon, Whaleback Ridge, and Antler Ridge reference sections. These similarities include the general constancy of composition of the high-silica rhyolite in the crystalpoor zone, the sharp geochemical break between the crystal-poor and crystal-rich zones, the very significant increases in the concentrations of $\mathrm{K}, \mathrm{Ca}, \mathrm{Sr}, \mathrm{Zr}, \mathrm{Ti}, \mathrm{Ba}$, $\mathrm{La}$, and $\mathrm{Ce}$ through the crystal-rich zone, and the decreases in $\mathrm{Rb}$ and $\mathrm{Nb}$ through the crystal-rich zone. However, two significant differences occur between the geochemical trends in samples from NRG\#3 and those defined by the reference sections. In the reference sections, $\mathrm{Ba}, \mathrm{Ti}$, and $\mathrm{Zr}$ are excellent markers of the contact between the crystal-rich and crystal-poor zones. These elements also delineate the contact in
NRG\#3 (fig. 3), but the geochemical break is not as clear as in the reference sections because of reversals in concentrations in the lower part of the crystal-rich zone. A second clear distinction between NRG\#3 and the reference sections is the rate of up-section element increase in the crystal-rich zone. For example, the variation in Ti can be approximated by a linear increase through the crystal-rich zone. In the Solitario Canyon, Antler Ridge, and Whaleback Ridge reference sections, Ti increases up section at 17 to $18 \mathrm{ppm}$ per $\mathrm{ft}$. In contrast, the increase through the crystal-rich zone in NRG\#3 is $37 \mathrm{ppm}$ per $\mathrm{ft}$. Similarly, the rate of increase in $\mathrm{Zr}$ is $4.8 \mathrm{ppm}$ per $\mathrm{ft}$ at Solitario Canyon, 5.5 at Whaleback, 5.3 and Antler, and 9.0 at NRG\#3 or nearly twice that of the reference sections.

Unpublished data for samples from drill hole UE-25 NRG\#2 provide possible further constraints on this apparent lateral geochemical variation in the crystal-rich zone of the Tiva Canyon Tuff. NRG\#2 is located $685 \mathrm{ft}$ east and $551 \mathrm{ft}$ south of NRG\#3. The vertical drill hole intercepted nonwelded tuffs and the vitric and crystal-rich zones of the Tiva Canyon Tuff (J. Geslin and T. Moyer, Science Applications International Corporation, written commun., 1993). After corrections are made for a $15^{\circ}$ dip to the east, the stratigraphic thickness of the interval between the base of the pumice-poor subzone and the top of the crystalrich zone is $72.9 \mathrm{ft}$. In NRG\#3, this same interval is only $58.8 \mathrm{ft}$ thick. The geochemical gradients in NRG\#2 are $29 \mathrm{ppm}$ Ti per $\mathrm{ft}$ and $7.2 \mathrm{ppm} \mathrm{Zr}$ per ft. These gradients are intermediate between those for the reference sections and for NRG\#3. If the gradients in NRG\#2 were compressed to reflect the stratigraphic thickness of the same interval in NRG\#3, the calculated gradients would be $8.9 \mathrm{ppm} \mathrm{Zr}$ per ft and $36 \mathrm{ppm} \mathrm{Ti}$ per $\mathrm{ft}$. The close agreement with the observed gradients in NRG\#3 suggests that some part of the crystalrich zone intercepted by the drill hole has been faulted out, resulting in the apparent compression of the geochemical gradients. Intersection of one or more west-dipping normal faults (west side down) by NRG\#3 would result in apparent thinning of the unit. Assuming that the crystal-rich zone intercepted by NRG\#2 has not been faulted, the integrated stratigraphic throw on the faults intercepted by NRG\#3 would be $14 \mathrm{ft}$. NRG\#3 is located close to the eastern side of a zone of closely spaced normal faults called the imbricate fault zone (Scott and Bonk, 1984). Thus, it is not unreasonable to postulate that NRG\#3 inter- 


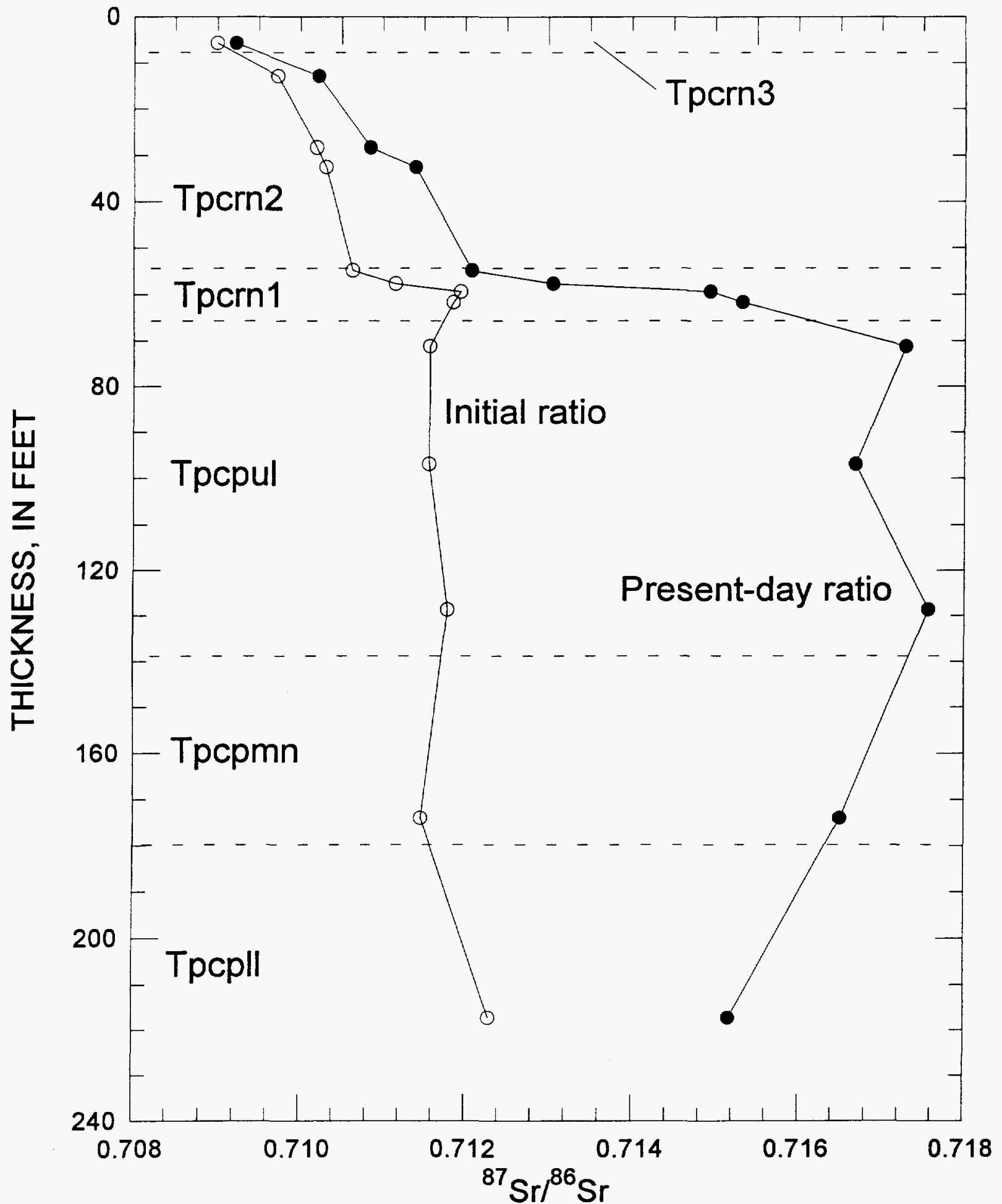

Figure 10. Variations of present-day and initial Sr-isotope ratios in samples of the Tiva Canyon Tuff from drill hole UE-25 NRG\#3. 

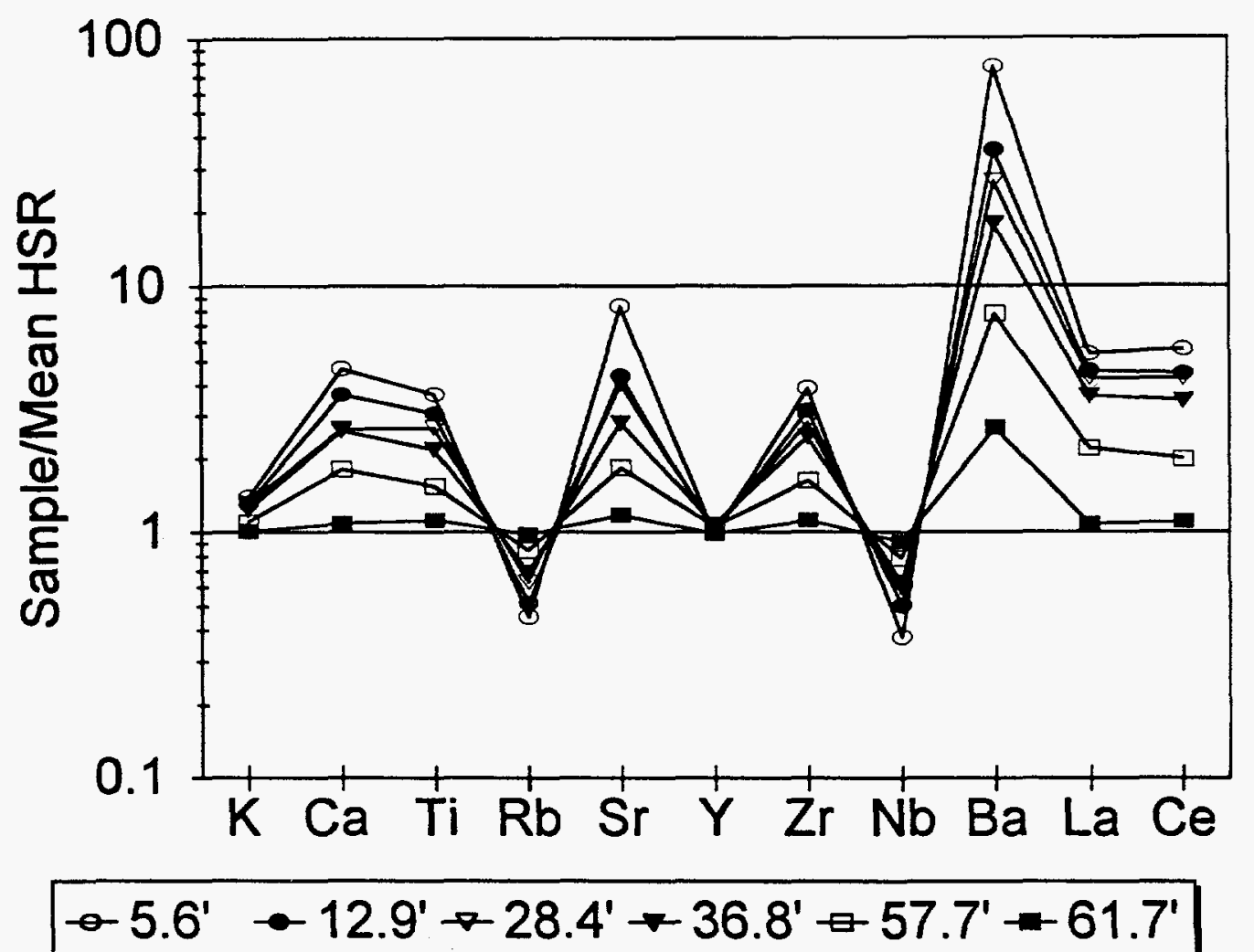

Figure 11. Comparison of element concentrations in selected samples of quartz latite with the mean values for high-silica rhyolite in UE-25 NRG\#3.

sected one or more normal faults that cut out part of the crystal-rich zone along the alignment of the drill hole. The validity of this postulate can be tested in the ESF, which will have penetrated the Tiva Canyon Tuff close to both NRG\#2 and NRG\#3.

The observation of larger geochemical gradients in NRG\#2 relative to those in the three reference sections also indicates a lateral change in these attributes, assuming that the section has not been faulted out along the drill hole. The existence of such lateral variations can be tested by establishing reference sections both east and west of the existing sections and drill holes. Use of the geochemical gradients to estimate stratigraphic throw along faults must consider these possible lateral changes in the gradients and rely on sections nearby the subject faults for reference.

\section{SUMMARY}

The distribution of the elements $\mathrm{K}, \mathrm{Ca}, \mathrm{Ti}, \mathrm{Rb}$, $\mathrm{Sr}, \mathrm{Y}, \mathrm{Zr}, \mathrm{Nb}, \mathrm{Ba}, \mathrm{La}$, and Ce in core samples of the Tiva Canyon Tuff from drill hole UE-25 NRG\#3 at Yucca
Mountain are similar to those observed in reference sections at Solitario Canyon, Whaleback Ridge, and Antler Ridge. Except for small differences, the highsilica rhyolite is laterally and vertically uniform in composition. The effects of alkali-element mobility have been observed in the lower vitric subzones of the Solitario Canyon reference section, but NRG\#3 and the other reference sections do not intercept these lower subzones. The contact between the crystal-poor (highsilica rhyolite) and the crystal-rich (transitional quartz latite) zones is clearly identified geochemically in NRG\#3, although some elements such as $\mathrm{Ba}$ and $\mathrm{Ti}$ show small-scale reversals in trend immediately above the contact.

The approximate monotonic increase in $\mathrm{Ba}, \mathrm{Zr}$, and $\mathrm{Ti}$, especially, through the crystal-rich zone can be used to estimate stratigraphic throw along faults where zonal contacts are obscured. However, the rate of increase in these elements in NRG\#3 is substantially larger than in the reference sections. Comparison of these trends and zonal thicknesses with those in 
NRG\#2, a nearby vertical hole that intercepts the crystal-rich zone of the Tiva Canyon Tuff, suggests the possibility that the intercepted crystal-rich zone at NRG\#3 has had approximately $14 \mathrm{ft}$ of section cut out by one or more normal faults. The rates of increase of elements stratigraphically upward in NRG\#2 are also larger than those observed at the reference sections, which also suggests lateral variability in these attributes.

\section{REFERENCES CITED}

Broxton, D.E., Warren, R.G., and Byers, F.M., 1989, Chemical and mineralogic trends within the Timber Mountain-Oasis Valley caldera complex, Nevada-Evidence for multiple cycles of chemical evolution in a longlived silicic magma system: Journal of Geophysical Research, v. 94, p. 5961-5985.

Buesch, D.C., Dickerson, R.P., Drake, R.M., and Spengler, R.W., 1994, Integrated geology and preliminary cross section along the north ramp of the Exploratory Studies Facility, Yucca Mountain: Fifth International Conference on High Level Radioactive Waste Symposium, v. 2, p. 1055-1065.

Byers, F.M., Jr., Orkild, P.P., Quinlivan, W.D., and Sargent, K.A., 1976, Volcanic suites and related cauldrons of Timber Mountain-Oasis Valley caldera complex, southern Nevada: U.S. Geological Survey Professional Paper 919, $70 \mathrm{p}$.

Cas, R.A.F., and Wright, J.V., 1993, Volcanic successionsModern and ancient: London, Chapman and Hall, $528 \mathrm{p}$.

Farmer, G.L., Broxton, D.E., Warren, R.G., and Pickthorn, W., 1991, Nd, Sr, and O isotopic variations in the metaluminous ash-flow tuffs and related volcanic rocks at the Timber Mountain/Oasis Valley caldera complex, SW Nevada-Implications for the origin of large-volume silicic magma bodies: Contributions to Mineralogy and Petrology, v. 109, p. 53-68.

Flood, T.P., Vogel, T.A., Schuraytz, B.C., 1989, Chemical evolution of a magmatic system-The Paintbrush Tuff, southwest Nevada volcanic field: Journal of Geophysical Research, v. 94, p. 5943-5960.

Geslin, J.K., Moyer, T.C., and Buesch, D.C., 1995, Summary of lithologic logging of new and existing boreholes at Yucca Mountain, Nevada-August 1993 to February 1994: U.S. Geological Survey Open-File Report 94-342, 39 p.

Hildreth, W., 1981, Gradients in silicic magma chambersImplications for lithospheric magmatism: Journal of Geophysical Research, v. 86, p. 10153-10192.
Johnson, C.M., 1989, Isotopic zonations in silicic magma chambers: Geology, y. 17, p. 1136-1139.

Lipman, P.W., 1965, Chemical comparison of glassy and crystalline volcanic rocks: U.S. Geological Survey Bulletin 1201-D, p. D1-D24.

Lipman, P.W., Christiansen, R.L., and O'Connor, J.T., 1966, A compositionally zoned ash-flow sheet in southern Nevada: U.S. Geological Survey Professional Paper 524-F, p. F1-F47.

Marshall, B.D., Kyser, T.K., and Peterman, Z.E., in press, Oxygen isotopes and trace elements in the Tiva Canyon Tuff, Yucca Mountain and vicinity, Nye County, Nevada: U.S. Geological Survey Open-File Report 95-431.

Noble, D.C., and Hedge, C.E., $1969,{ }^{87} \mathrm{Sr} /{ }^{86} \mathrm{Sr}$ variations within individual ash-flow sheets: U.S. Geological Survey Professional Paper 650-C, p. C133-C139.

Peterman, Z.E., Spengler, R.W., Futa, K., Marshall, B.D., and Mahan, S.A., 1991, Assessing the natural performance of felsic tuffs using the $\mathrm{Rb}-\mathrm{Sr}$ and $\mathrm{Sm}-\mathrm{Nd}$ systems-A study of the altered zone in the Topopah Spring Member, Paintbrush Tuff, Yucca Mountain, Nevada in Scientific Basis for Nuclear Waste Management XIV, Pittsburgh, Penn., Materials Research Society, p. 687-694.

Schuraytz, B.C., and Vogel, T.A., 1989, Evidence of dynamic withdrawal from a layered magma body-The Topopah Spring Tuff, southwestern Nevada: Journal of Geophysical Research, v. 94, p. 5925-5942.

Scott, R.B., and Bonk, J., 1984, Preliminary geologic map of Yucca Mountain, Nye County, Nevada, with geologic sections: U.S. Geological Survey Open-File Report 84-494, scale 1:12,000.

Singer, F.R., Byers, F.M., Jr., Widmann, B.L., Dickerson, R.P., 1994, Petrographic and geochemical characteristics of a section through the Tiva Canyon Tuff at Antler Ridge, Yucca Mountain, Nevada in High Level Radioactive Waste Management, Proceedings of the 5th International Conference, Las Vegas, Nev., 1994, La Grange Park, III., American Nuclear Society and American Society of Civil Engineers, p. 1869-1879.

Smith, R.L., 1979, Ash-flow magmatism in Chapin, C.E., and Elston, W.E., eds., Ash-flow tuffs: Geological Society of America Special Paper 180, p. 5-27.

Tegtmeyer, K.J., and Farmer, G.L., 1990, Nd isotopic gradients in upper crustal magma chambers-Evidence for in situ magma-wall-rock interaction: Geology, v. 18, p. 5-9. 


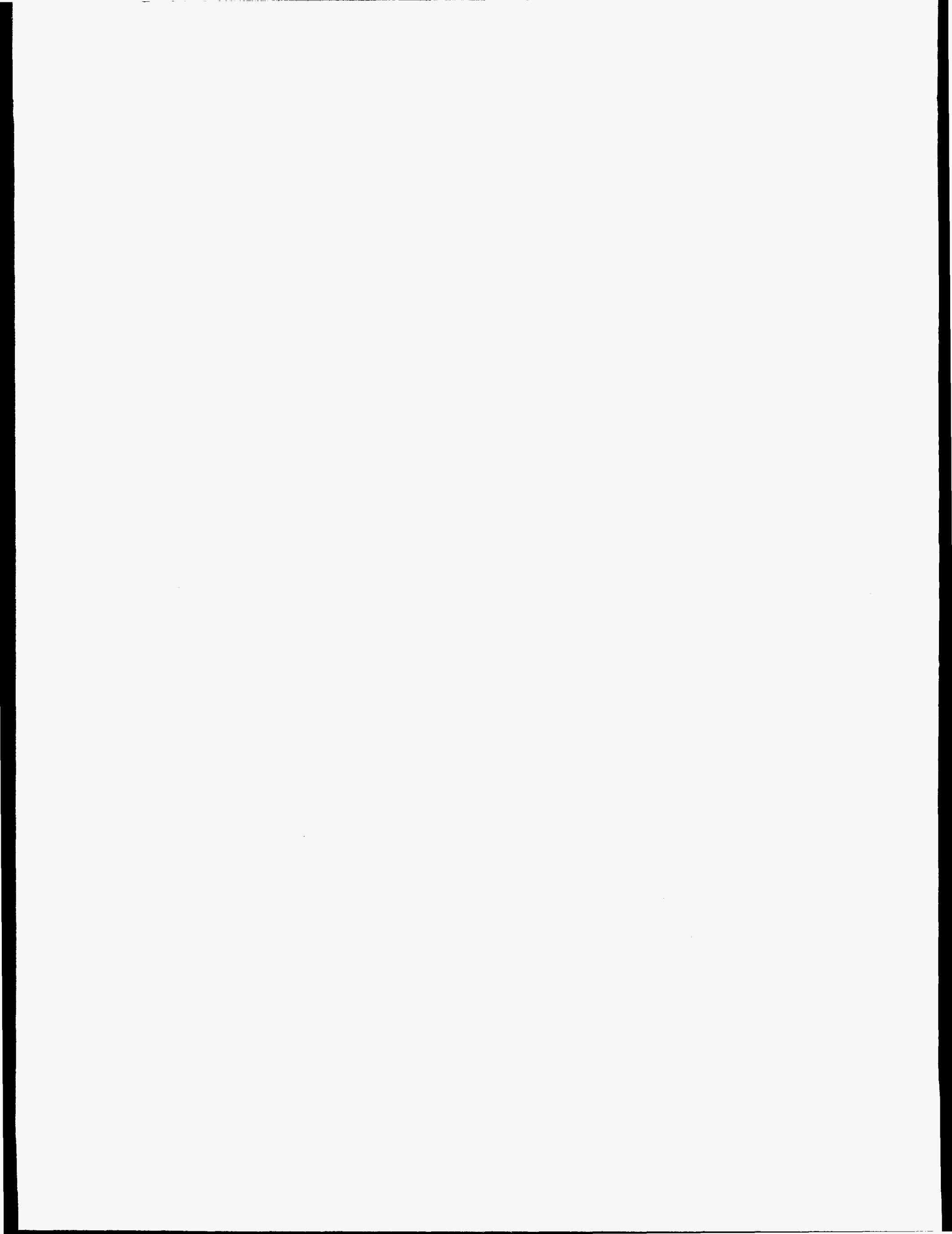

